to occur in species which are usually hermaphrodite. Whether they occur in a gynodioecious or gynomonoecious manner, these pistillate flowers are regularly smaller than the hermaphrodite ones ${ }^{22}$. By contrast, where androdioecism or andromonoecism occurs, the staminate flowers are generally as large as hermaphrodites. In at least six families which show what appears to be evolutionarily recent dioecism, there is a similar contrast between pistillate and staminate flower-sizes. This suggests that, although the separation of the sexes has undoubtedly evolved many times in the phylogeny of the flowering plants, the hormonal control of sex-expression is likely to be a relatively simple and general one and may well be connected with the level of auxin-activity in the developing flower-bud. In at least some gynodioecious members of the Labiatae, the abortion of the anthers is associated with a dwarfing of the plant in all its aerial parts.

Botany Department,

University College of Ghana, Achimota.

${ }^{1}$ Heslop-Harrison, J., Biol. Rev., 32, 38 (1957).

${ }^{2}$ Lambert, J., J. Ecol., 34, 310 (1947).

${ }^{3}$ Erlenmeyer, H., and Geiger-Huber, M., Helv. Chim. Acta, 18, 921 (1935).

- Baker, H. G., Ann. Bot. Lond., N.S., 11, 333 (1947).

${ }^{5}$ Schopfer, W.-H., and Blumer, S., Arch. Mikrobiol., 9, 305 (1938).

${ }^{6}$ Schopfer, W.-H., and Blumer, S., Verh. Schweiz. Naturf. Ges., 120, $61(1939)$.

'Schopfer, W.-H., and Blumer, S., Ber. schweiz. bot. Ges., 49, 414 (1939).

${ }^{8}$ Schopfer, W.-H., and Blumer, S., Z. Vitaminforsch., 9, 344 (1939)

* Blumer, S., Phytopath. Z, 13, 375 (1941)

${ }^{10}$ Schopfer, W.-H., C.R. Acad. Sci., Paris, 210, 703 (1940)

11 Schopfer, W.-H., Verh. schweiz. naturf. Ges., 122, 151 (1941).

${ }^{12}$ Schopfer, W.-H., C.R. Soc. Phys. Hist. nat. Genève, 58, 112 (1941)

${ }^{13}$ Schopfer, W.-H., Boissiera, 7, 219 (1943).

is Baker, H. G. Nature, 159, 34 (1947).

${ }^{15}$ Baker, H. G., Genetica, 25, 126 (1950)

${ }^{18}$ Westergaard, M., Hereditas, 32, 60, 419 (1946)

17 Westergaard, M., Hereditas, Lond., 34, 257 (1948).

${ }^{28}$ Westergaard, M., Naturwiss., 9, 253 (1953).

10 Werth, E., Mitt. Kais. Biol. Anstalt., Land-u. Forstw., 9, 12 (1912)

${ }^{20}$ Plowright, C. B., "A Monograph of the British Uredineae and Ustilagineae" (London, 1889).

${ }^{21}$ Plowright, C. B., Gard. Chron., 11, 271 (1892).

${ }^{22}$ Baker, H. G., Proc. Leeds Phil. Lit. Soc., 5, 136 (1948).

\section{Mast Cells in the Epithelium of the Esophagus}

MAST cells in epithelium are considered to be extremely rare, and those who have noted them in this site consider that they have migrated from other tissues ${ }^{1}$. During a study of the structure of the mucous membrane of the cesophagus in the adult cat, we have been impressed by the constant finding of large numbers of mast cells in the epithelium. Basic lead acetate was used as a tissue fixative and metachromasia was demonstrated by staining with azure $A$ or with toluidine blue. The mast cells are situated in the basal layers of the epithelium (Fig. 1), and were never observed in the more superficial regions. Although comparative counts have not yet been carried out, it appeared that the epithelium of the cranial two-thirds of the osophagus contained fewer mast cells than the caudal third where, in any highpower field, as many as seven cells might be found. From the present work, in which the oesophagi of thirty animals have been examined, no evidence can be put forward to suggest that these mast cells appear in the epithelium as the result of migration

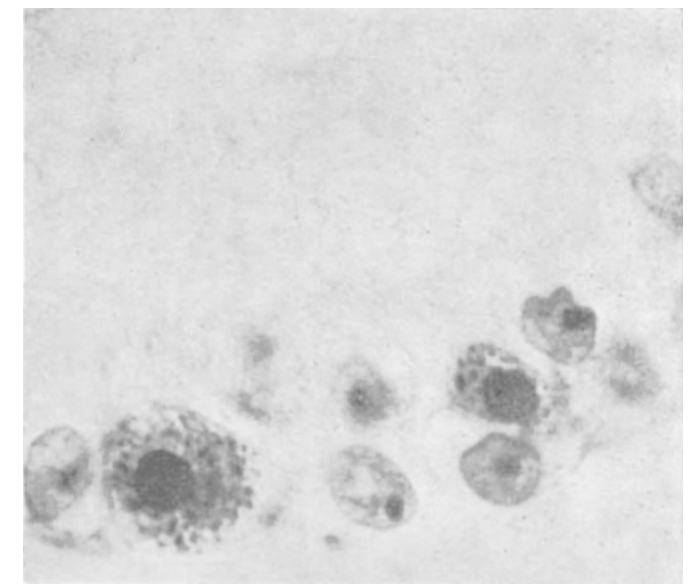
Fig. 1. Two mast cells in the basal epithelial layer of the
osophagus. $(\times 1,340)$

from the subepithelial tissues, or that they migrate within the epithelium itself.

During the study of wound healing in the mucous membrane of the œsophagus ${ }^{2}$, mast cells were not found among the regenerating epithelial cells until after epithelialization had become complete.

The significance of these findings, and of other work now in progress on the distribution of mast cells in different animals of varying ages, will be discussed fully elsewhere.

F. R. Johnson

R. M. H. MeMran

Department of Anatomy,

University of Sheffield. May 16.

${ }^{1}$ Asboe-Hansen, G., Int. Rev. Cytol., 3, 399 (1954).

${ }^{2}$ McMinn, R. M. H., and Johnson, F. R. (in the press).

\section{Latent Infection of Rabbits by Adenovirus Type 5}

Adenoviruses were first isolated by Rowe, Huebner, Gilmore, Parrott and Ward ${ }^{1}$ from cultures of human adenoids undergoing spontaneous degeneration. The same group of workers ${ }^{2}$ observed that these agents can be isolated from a large proportion of adenoids and tonsils after these tissues are grown in vitro for a certain time. Attempts to isolate the virus by direct inoculation of tissue homogenates into cultures of susceptible cells usually resulted in failure which was attributed to the presence of virus-neutralizing antibody demonstrated in these tissue homogenates. The process of 'unmasking' of the virus in tissue cultures would be a consequence of dilutions of this antibody as a result. of successive fluid changes during tissue cultivation. Similar phenomena have been reported in the study of poliomyelitis ${ }^{3,4}$, salivary gland virus $^{5}$, influenza ${ }^{6}$, psittacosis $^{7}$ and typhus rickettsix ${ }^{8}$, and different mechanisms have been suggested to explain virus unmasking.

By the use of tissue cultures we have been able to demonstrate the persistence of adenovirus type 5 in the spleen of adult rabbits for periods up to 8 weeks after inoculation. In a representative experiment, six rabbits were inoculated intravenously with $10^{9.2} 50$ per cent tissue culture doses of the prototype strain of adenovirus type 5. The animals were bled at intervals for measurement of antibody pro- 